\title{
Analysis on Operation Management of Logistics Park in China
}

\author{
Xiangru Meng ${ }^{1, *}$, Jianmeng Sun $^{2}$, and Haining Wang ${ }^{3}$ \\ ${ }^{1}$ Shandong Vocational University of Foreign Affairs, Weihai 264504, China \\ ${ }^{2}$ Shandong Institute of Transportation Science, Jinan, Shandong Province, China \\ ${ }^{3}$ Shandong Hi-speed Group Co., Ltd, Jinan, Shandong Province, China
}

\begin{abstract}
Since the State Council issued the "Plan for the Adjustment and Revitalization of the Logistics Industry" in 2009, the logistics industry, as the basic and strategic industry in the development of the national economy, has played an increasingly important role in promoting industrial transformation and upgrading and promoting economic development. In order to promote the development of logistics industry, a large number of logistics parks have been built all over the country under the guidance of policies and the promotion of the market. However, after the construction of these logistics parks has been put into operation, There are a series of problems in its development and profit. This paper analyzes the present situation and profit of logistics park in China, and briefly analyzes the main business characteristics of freight hub, production service, port service, trade service and comprehensive service. On this basis, the main problems existing in the existing profit model of logistics park in China are summarized.
\end{abstract}

\section{Introduction}

The definition of logistics park in the National Standard of the People's Republic of Chinas Republic of China is: in order to realize the intensification of logistics facilities and the commonization of logistics operation, or for the purpose of rationalizing the spatial layout of urban logistics facilities, the logistics facilities group and many logistics practitioners are physically assembled in the region. Under the influence of national nature and national system, China's logistics park has two main attributes, that is, public welfare and enterprise of logistics park. Its public welfare is mainly reflected in improving logistics efficiency, improving traffic conditions, reducing environmental pollution, enhancing the comprehensive competitiveness of the city, and its enterprise is mainly reflected in affecting the operating costs and profit space of the resident customers, participating in investment construction and management by enterprises, and directly or indirectly participating in market competition. The profit model of logistics park is mainly aimed at the enterprise of logistics park. The design of profit pattern of logistics park is an important link in the process of logistics park operation and management.

Because the political, cultural and economic conditions of European countries are different from those of China, the operation and management of logistics parks also show different characteristics and [2].Britain, Germany, Spain, France and other countries of logistics parks, most of the use of public-private joint operation management model (PPP model).Because logistics parks in many European countries reflect their public service function rather than profit [3].Germany generally adopts the development mode of the federal government's overall planning, the state government and the municipal government to support the construction and the independent management of the resident enterprises, and regards improving the economy and rationality of freight transportation as the main purpose of the development of the logistics park。German logistics park profit model has two main types: first, the government through leasing good public logistics facilities to obtain rent; second, management enterprises through the provision of by providing excellent logistics related services.

Japan's logistics park operation and management operation and management modes in Japan, there are four kinds of [5]: co-financing mode, individual management mode, semi-official mode and cooperative combination mode. Due to its small area, Japan's main purpose of developing logistics parks is to relieve urban traffic pressure. Japan's logistics park development model adopts macro-level overall control, micro-level free and open way, profit model is mainly through speeding up the development of transportation infrastructure, while promoting the development of logistics enterprises, Promote the land price and real estate appreciation of logistics park, so that investment returns [4].

\section{Operation Management Mode of Logistics Park}

Logistics park operation management involves planning and construction in the early stage of development and the management of daily business activities after the park is put into operation. As for the development mode of logistics park, there are many ways in our country, such as

* Corresponding author: mxr6465201@126.com 
"government planning, enterprise leading "," enterprise independent development "," government planning leading "," government planning, industrial real estate developer leading" and so on. Among them," government planning and enterprise leading "are still the main ways of development and construction of logistics park in our country, accounting for $65 \%$ of them. In addition, in the actual production life, most of the logistics parks are developed by stages of construction, construction and operation. Although the development methods of different logistics parks are different, the purpose of their operation is the same, that is, to maximize social and economic benefits. This paper studies the management of logistics park, focusing on the management level of the park. The connotation of the operation mode of the logistics park is defined as: after the whole or part of the logistics park is planned and constructed, with the support of the relevant government policies, the main strategic and management activities of the logistics park are designed through the establishment of an appropriate organization and management system.

After entering the operation stage, the main body of operation in different parks may be different. The operation and management of logistics parks in China are dominated by the independent operation of enterprises and the operation of government management committees, accounting for $65 \%$ and $32 \%$ respectively. In the park, the professional operation management company is responsible for the management of the park's business activities, and the degree of marketization is high. In the park run by the government management committee, the direct participation of the management committee in the operation is gradually decreasing, and the separation of government and enterprise is an important trend at present . The Administrative Committee is the main body of administration, as the accredited agency of the government, which exercises administrative functions in the logistics park, provides administrative services for the enterprises in the park, and is operated by a specially established operation management company, Responsible for the daily operation of the park related work, park operation of the city. The level of fieldization is getting higher and higher.

\section{Type Analysis of Logistics Park}

According to the content of the National Logistics Park Development Plan (2013-2020), the logistics park of our country can be divided into five categories according to the leading business function and the service object, which can be divided into freight hub type, production service type, port service type, trade service type and comprehensive service type.

\subsection{Freight Hub Logistics Park}

In terms of business characteristics, freight hub logistics park is based on transportation hub, with more than two modes of transportation. Logistics Park has the logistics facilities to provide large-volume cargo transshipment, can provide services for international or regional cargo transit. Freight hub logistics park business, mostly related to the transfer of goods.

In terms of revenue source, the freight hub logistics park has the characteristics of freight transfer station. At present, the income of logistics park is mainly based on freight forwarding, warehousing and distribution, supplemented by the income of goods processing, trade services and other supporting services. Because this kind of park generally relies on the wharf, the railway hub, the airport and so on transportation hub to carry on the construction, has the certain geographical superiority, often will focus on a certain cargo transshipment business to carry on the profit. For example, Funing Port Logistics Park, based on Tongyu River and Sheyang River, serves wind power, photovoltaic, building materials and other industries in six counties of three cities around Funing. At present, it mainly obtains income in the leasing of terminal supporting facilities and equipment, as well as the storage and transshipment of containers and large equipment.

\subsection{Trade Service Logistics Park}

In terms of business characteristics, trade and service logistics parks often rely on large urban commercial circles, wholesale market professional markets, can provide business enterprises with transportation, distribution, warehousing and other logistics services as well as commodity display, e-commerce, financing insurance and other supporting services to meet the general commercial and commodity trade logistics needs.

In terms of income sources, the income of the business service logistics park is generally derived from the trading places and storage facilities provided to customers, supplemented by the income of logistics services such as circulation processing, sorting and packaging. Such as Yangzhou Trade Logistics Park, relying on the East International Food City and other professional market business logistics demand, from the offline trade market related facilities and equipment and trading venues rental, property management and other aspects of income.

\subsection{Production Service Logistics Park}

In terms of business characteristics, production-oriented logistics parks are often adjacent to industrial parks or super-large manufacturing enterprises. The logistics park can provide integrated supply chain services such as purchasing and supply, inventory management, material planning, on-time distribution, capacity management, collaborative processing, transportation distribution, information services, distribution trade and financial insurance for manufacturing enterprises to meet the logistics needs of manufacturing enterprises such as material supply and product sales

In terms of income sources, the revenue of the production-oriented logistics park is generally based on the revenue of goods storage services, supplemented by the revenue of goods distribution and wholesale transaction services. Because this kind of park construction often relies on the large industrial park or the production and manufacturing enterprise, therefore 
generally adopts the management strategy which strives for several large customers, through provides the largescale warehousing, the distribution business, collects the warehouse rental fee, the property management fee and so on. For example, Yizheng Automobile Logistics Park, above Auto Volkswagen Yizheng Factory as the key service object, from the parts storage facilities and vehicle manufacturing site rental and other aspects of income..

\subsection{Port Service Logistics Park}

In terms of business characteristics, port service logistics parks often rely on port establishment, which can provide customs declaration, inspection, warehousing, international procurement, distribution and distribution, international transit, international transit trade goods display and other services to meet the logistics needs of international trade enterprises. Because the port logistics park usually relies on the port, the land port and so on and the container transportation and the customs supervision channel unifies the large-scale transshipment hub establishment, the development bonded logistics business has the very big superiority.

In terms of income sources, port logistics parks generally collect storage and processing fees through bonded warehousing, bonded processing and other business. Such as the Shanghai Cooperation Organization (Lianyungang) International Logistics Park, relying on the establishment of Lianyungang port, to carry out international container distribution, bonded warehousing and other business, from bonded warehouse leasing and container transit transport and other aspects of income.

\subsection{Integrated Service Logistics Park}

In terms of business characteristics, integrated service logistics parks usually have more than two modes of transportation, which can realize multimodal transport and seamless connection. The logistics park can provide at least two or more services in freight hub, trade service, production service, port service, and meet the scale logistics needs of cities and regions. In general, the integrated service logistics park will focus on the development of 2-3 kinds of logistics services according to the actual situation of the local market.

In terms of income sources, the income sources of integrated service parks are relatively extensive, but at present they are generally more basic. Carry out distribution business in combination with goods transaction, collect transaction site rental fee and distribution service fee; Carry out cargo transaction service in combination with transshipment business, set up large area warehouse group and trading place, collect warehouse rental fee, property management fee and freight forwarding fee, etc. Such as Wuxi West Station Logistics Park, relying on Wuxi West Station to establish, carry out urban distribution, metal supply chain logistics and e-commerce logistics and other different business, from e-commerce office rental, steel storage and transportation and distribution of consumer goods and other aspects of income.

\section{Development Analysis of Logistics Park}

\subsection{Analysis Analysis of Logistics Park}

According to the National Logistics Park (Base) Survey Report issued by China Logistics and Purchasing Network, in terms of the number of logistics parks, a total of 1210 logistics parks were operated, under construction and planned throughout the country in 2015. The number of logistics parks increased by $60 \%$ compared with the results of the last national logistics park (base) survey. In terms of the types of logistics parks, according to the classification of logistics parks in the National Logistics Park Development Plan (2013-2020), there are five types of logistics parks: freight hub type, production service type, port service type, trade service type and comprehensive service type. As shown in Fig.1.

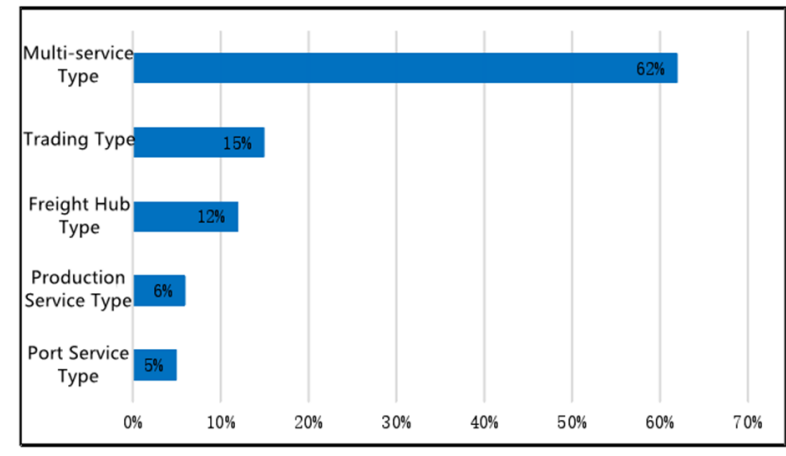

Fig.1. Type of Logistics Park

\subsection{Analysis of Main Business Function of Logistics Park}

In terms of the business functions of the park, the business functions of the logistics park are divided into the main business functions related to logistics, the basic supporting service functions provided by the park, and the derived government and business service functions. Overall, the main business functions of the logistics park, warehousing, transportation and distribution and other traditional business occupies a dominant position; Parking, catering, accommodation, property and security dominate in basic support services; Government and business services, mainly information, business and tax services. As shown in Fig.2.

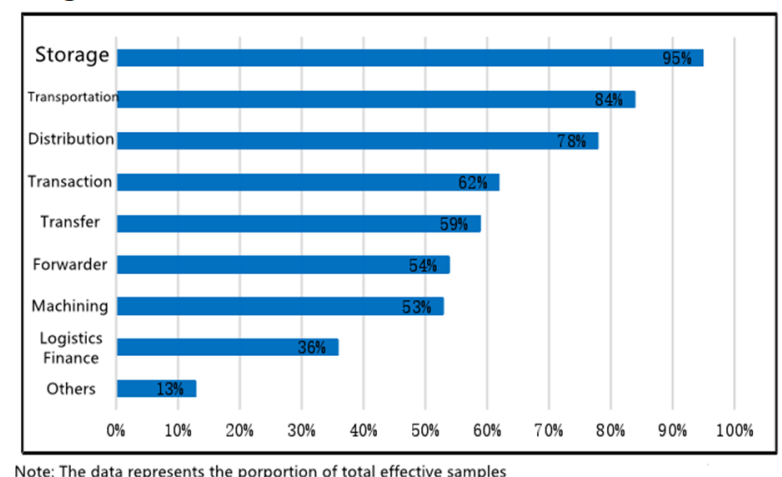

Fig.2. Main business functions of Logistics Park 


\subsection{Analysis of Main Income Sources in Logistics Park}

Profit is an important embodiment of the economic benefits of the logistics park. In terms of the income source of the logistics park, the income of the logistics park in our country is mainly property leasing, storage and transportation and distribution; In terms of the factors affecting the profit of the park, three main factors are the market competition, the insufficient effective demand of logistics and the change of operating cost, which reflects the fierce market competition between the logistics parks in the aspect of profit. As shown in Fig.3.

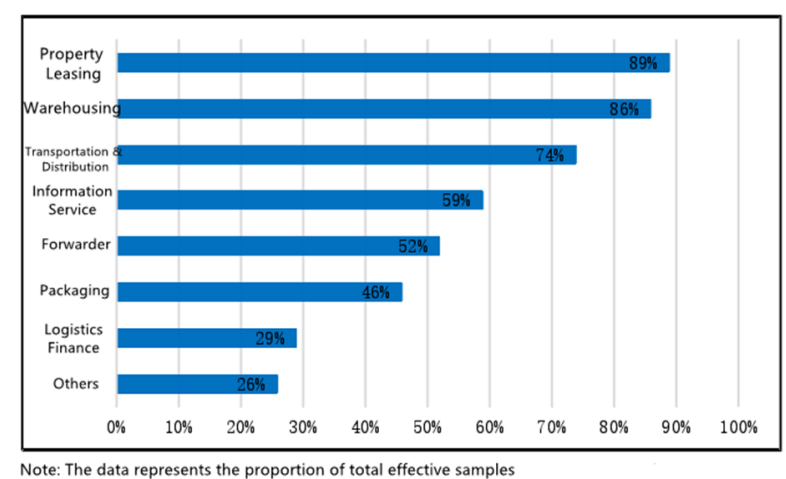

Fig.3. Main sources of revenue for logistics parks

\subsection{Analysis of the Main Factors Affecting Profit of Logistics Park}

The main factors affecting the profits of the logistics park are shown in Fig. 4.

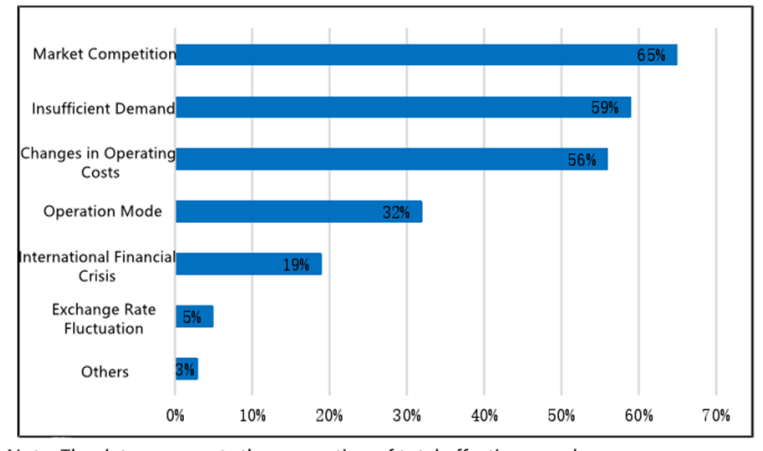

Note: The data represents the proportion of total effective samples

Fig. 4. Main Factors Affecting the Profit of Logistics Park

\section{Conclusions}

The main revenue source of logistics park in China is property leasing, storage and transportation and distribution, and the profit of the park is most affected by market competition, effective demand of logistics and operating cost. Most of the freight hub logistics park's business is related to current universal source of revenue is freight forwarding, warehousing, distribution, cargo processing operations, trade services and other supporting services as a supplement; Trade and service logistics park mainly meet the general commercial and commodity trade logistics needs, its income generally comes from the trading places and storage facilities provided to customers, supplemented by circulation processing, sorting packaging and other logistics services income; The production service logistics park mainly meets the material supply and product sales logistics demand of manufacturing enterprises. At present, the income of goods storage service is the main one, supplemented by the income of goods distribution and wholesale transaction service; Port service logistics park mainly meet the logistics needs of international trade enterprises, generally through bonded warehousing, bonded processing and other business to collect warehousing, processing and other costs; The integrated service logistics park focuses on meeting the scale logistics needs of cities and regions. At present, the source of income is generally more basic, such as transaction site rental fee, distribution service fee, warehouse rental fee, property management fee, freight forwarding fee and so on.

\section{Acknowledgment}

This paper was subsidized by Construction Project of quality Curriculum for Postgraduate Education in 2018 (SDYKC18098) in Shandong Province.

\section{References}

1. Sulgan M. Logistics Park Development in Slovak Republic[J]. Transport Research Journal of Vilnius Gediminas Technical University \& Lithuanian Academy of Sciences, 2006, 21(3):197-

2. Zhang Juan, Xu Yandan. Analysis on Profit Concept of Logistics Park MarketWeek: Theoretical Studies ,2011(8):29-30.

3. Zhang Guo. A Study on the Mode of Operation of County Logistics Park [D] Nanjing University ,2015.

4. Ma Miaoming. A Study on the Profit Patterns of Logistics Parks in Different Development Stages [J]. Business Economics Research ,2011(22):36-37.

5. Zhang Daochen. A Study on Operation Mode of Logistics Park [D] Beijing Jiaotong University ,2009. 